\title{
The Formation and Elimination of the Negative Influence of Porosity on the Properties of the Alloy Castings AlSi10Mg
}

Iryna Hren, Milan Luňák, Sylvia Kuśmierczak

Faculty of Mechanical Engineering, J. E. Purkyne University in Usti nad Labem. Pasteurova 3334/7, 40001 Usti nad Labem. Czech Republic. E-mail: iryna.hren@ujep.cz, milan.lunak@ujep.cz, sylvia.kusmierczak@ujep.cz

\begin{abstract}
Aluminum alloys are often contaminated with non-metallic inclusions. A large number of these phases accelerate the tendency of porosity in castings, significantly reduce corrosion resistance and above all affect mechanical properties. Melting is one of the conventional methods for removing inclusions from melt. The efficiency of this process is influenced by several parameters such as the chemical composition of the melt, the amount of refining substances (wire, salts, tablets), the melting point and the casting method. Therefore, an experiment was performed to evaluate the effect of PROBAT FLUSS MIKRO 100 on the structural integrity in AISi10Mg alloy. Porosity evaluation was performed by light microscopy. To confirm the results and their reflexes into the practical production of castings, a static tensile test was performed on the cast samples directly in the foundry operation.
\end{abstract}

Keywords: AlSi10Mg alloy, casting defects, porosity, static tensile test

\section{Introduction}

Foundry alloys based on aluminum are widely used to produce a wide variety of castings in mechanical engineering, such as components for aircraft power units, aircraft fuselage, and especially for the automotive industry in general. These alloys are characterized by excellent technological properties that ensure the reliability of their function in difficult conditions. It is possible to talk about parts of internal combustion engines, etc. For this purpose, alloys based on binary systems $\mathrm{Al}-\mathrm{Si}$ and $\mathrm{Al}-\mathrm{Mg}$ and their alloying with various additives are used.

It is generally known that aluminum alloys dissolve hydrogen during its preparation by melting. The hydrogen content of the liquid metal is determined by the temperature and melting time regimes and the rate of use of the melting means to prevent the melt from over-saturating with hydrogen. As a subsequent process step after the alloy melting, it is the melt degassing to reduce the amount of hydrogen contained in the melt significantly. Typically, degassing is effected by introducing chlorine compounds into a melt, for example, magnesium chloride $\mathrm{MnCl}_{2}$ or more efficient hexachloroethane $\mathrm{C}_{2} \mathrm{Cl}_{6}$. As a result of the interaction of these compounds with hydrogen, $\mathrm{HCl}$ vapors are formed which evaporate from the melt. There are other means and methods for reducing the hydrogen content of the melt, which utilize the principle of expelling hydrogen from the melt by means of an internal gas, be it nitrogen or argon.

In general, the use of refining agents increases the efficiency of removing inclusions from the melt since they have suitable wettability with oxides and inclusions. Most fluxes contain fluoride compounds such as $\mathrm{Na}_{3} \mathrm{AlF}_{6}, \mathrm{CaF}_{2}, \mathrm{Na}_{2} \mathrm{SiF}_{6}$, which accelerate wettability [8-10]. Heterogeneous nucleation of pores in inclusions is highly probable [11-13]. The high interfacial energy between the inclusions and the molten aluminum causes the concentration of dissolved hydrogen and then the formation of hydrogen $\left(\mathrm{H}_{2}\right)$ molecules in the melt [14], which is.

Melting refining for aluminum castings is a complicated process, therefore attempts have been made to improve the quality of castings produced by gravity casting technology directly during their production. The aim of this article is to point out the importance of the method of refining the melt with a selected preparation and thus to supplement insufficient or unavailable information on this issue. The experiment is focused on the evaluation of the effect of PROBAT FLUSS MICRO 100 on the structural integrity and influence on selected mechanical properties in AlSi10Mg alloy.

\section{Experiment}

The alloy AlSi10Mg according to ČSN EN 424331 was used as an experimental material. The alloy was melted in a gas crucible melting furnace and subsequently cast by gravity casting into a preheated metal mold at a temperature of $300 \pm 30^{\circ} \mathrm{C}$. The melt temperature was maintained at $720 \pm 5^{\circ} \mathrm{C}$. The molten metal was purified by refining salt before casting. The melt was not modified. Chemical analysis of AlSi10Mg aluminum alloy was performed using spectral analysis on a TASMAN Q4 spark optical emission spectrometer. The chemical composition is given in Table 1. 
Tab. 1 Chemical composition of experimental melt

\begin{tabular}{|c|c|c|c|c|c|c|c|c|c|c|}
\hline $\mathrm{Si}$ & $\mathrm{Fe}$ & $\mathrm{Cu}$ & $\mathrm{Mn}$ & $\mathrm{Mg}$ & $\mathrm{Cr}$ & $\mathrm{Zn}$ & $\mathrm{Pb}$ & $\mathrm{Ti}$ & $\mathrm{Ni}$ & $\mathrm{Al}$ \\
\hline 9.91 & 0.25 & 0.025 & 0.25 & 0.23 & - & 0.017 & - & 0.11 & 0.005 & residue \\
\hline
\end{tabular}

The experimental alloy has a chemical composition in accordance with the material standard. The next step in the experiment was the use of the special preparation PROBAT FLUSS MIKRO 100 in various concentrations: $0.05,0.1$ to $0.2 \mathrm{wt}$. \%. The samples were cast into the preheated metal mold by the same casting technology in an effort to achieve as much technological conditions as possible (melt temperature, mold temperature, same mold filling time, etc.) compared to conventional manufacturing practice.

2.1 Microscopic evaluation of structure - optical microscopy

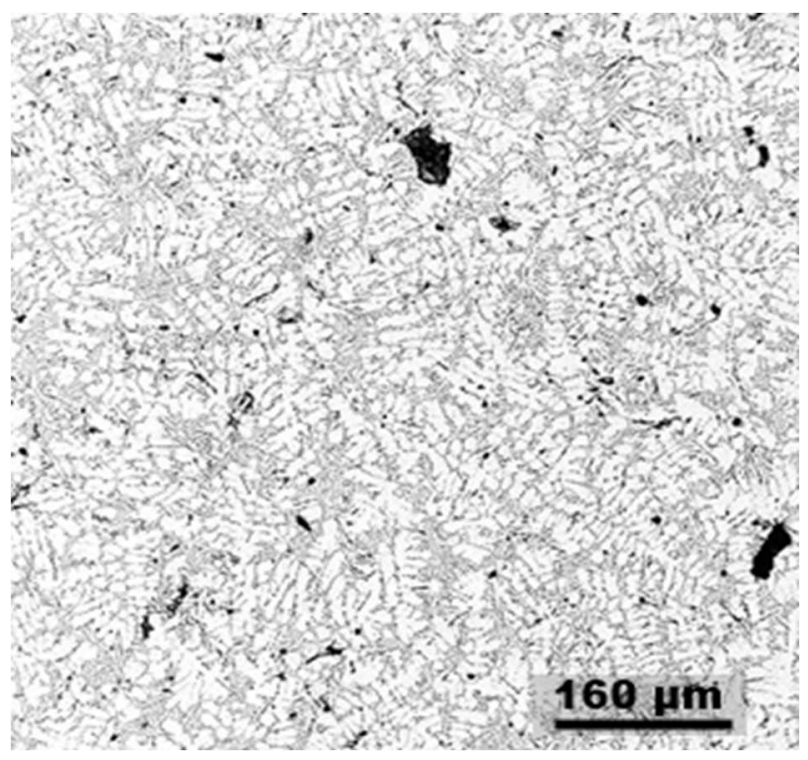

Fig. 1 Typical microstructure of AlSi10Mg alloy, mag. 100

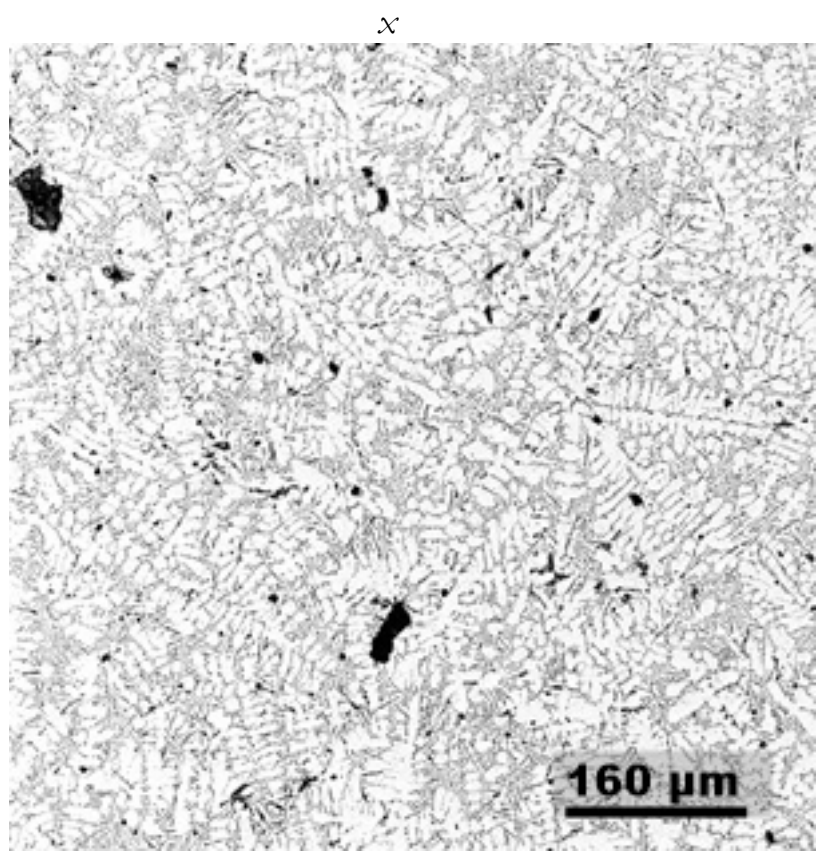

For examination of the microstructure of the samples was used a confocal laser microscope Olympus LEXT OLS 3100. The microstructure (Fig. 1) is typical of the size and distribution of the two main phases, a solid solution matrix (light phase) and interdendritic eutectic Si-particles (dark phase). This alloy belongs to the group of silumines, which are characterized by very good foundry properties, i.e. good run-in, low shrinkage and low tendency to crack, and also good corrosion resistance.

In order to evaluate the porosity in the experiment, four samples of different macro-porosity were taken from the experimental castings, which were labeled A1, A2, A3, A4. The sample labeled A1 showed the highest macro-porosity, while the sample A4 showed the lowest porosity. Metallographic sections were prepared from these samples for quantitative measurement of porosity. Five pore size measurements were taken for each sample. Porosity was measured in different areas of the cut using an Olympus LEXT OLS 3100 laser confocal microscope using image analysis.

\section{Sample A1}

The sample material A1 showed the highest porosity of all samples examined. In some areas of sample A1 pores appeared which were already visible to the naked eye. The areas with the largest pores are documented in Figure 2 (2.5\% porosity of the image area). In Table 2 shows the measured porosity of the sample A1, for which the average porosity value is $1.2 \%$ of the image area.

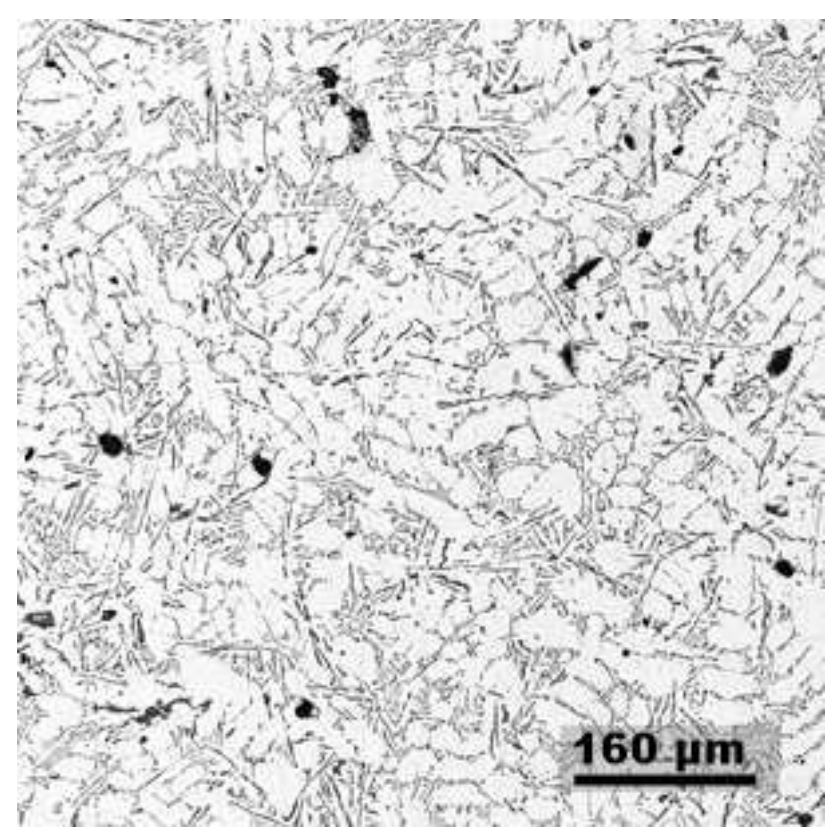

Fig. 2 Sample A1, microstructure with porosity, mag. $100 x$ 
Tab. 2 Measurement of porosity of sample A1 cast from AlSi10Mg alloy

\begin{tabular}{|l|l|l|l|l|l|l|l|l|l|l|l|}
\hline Measurement, $\mathrm{N}_{\circ}$ & 1 & 2 & 3 & 4 & 5 & 6 & 7 & 8 & 9 & 10 & $\begin{array}{l}\text { Arithmetic mean [\% of } \\
\text { image area }]\end{array}$ \\
\hline $\begin{array}{l}\text { Porosity } \\
{[\% \text { of image area }]}\end{array}$ & 1.3 & 1.5 & 1.3 & 1 & 1.4 & 1.8 & 1.3 & 1.9 & 1.1 & 1.6 & 1.4 \\
\hline
\end{tabular}

\section{Sample A2}

The microstructure of the sample A2 with the measured porosity $(0.13 \%$ of the image area $)$ is shown in Fig. 3. There was no difference in size and shape of

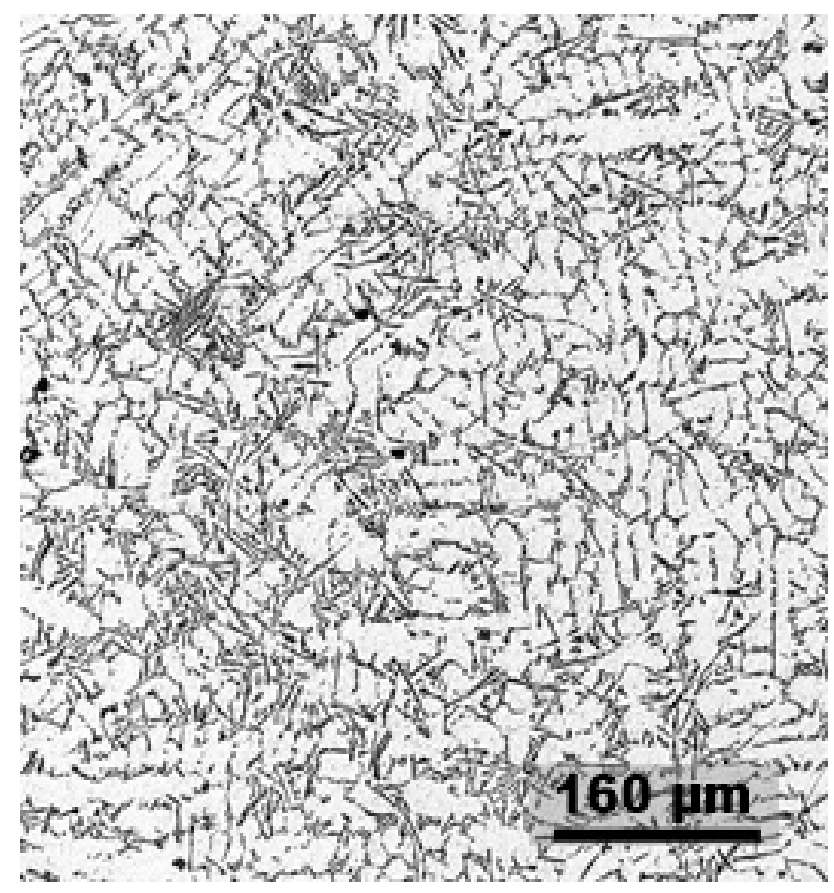

dendritic cells and excluded intermetallic phases compared to microstructures of sample A1. The values of the measured porosity of sample A2 are shown in Tab. 3 with an average porosity value of $0.057 \%$ of the image area.

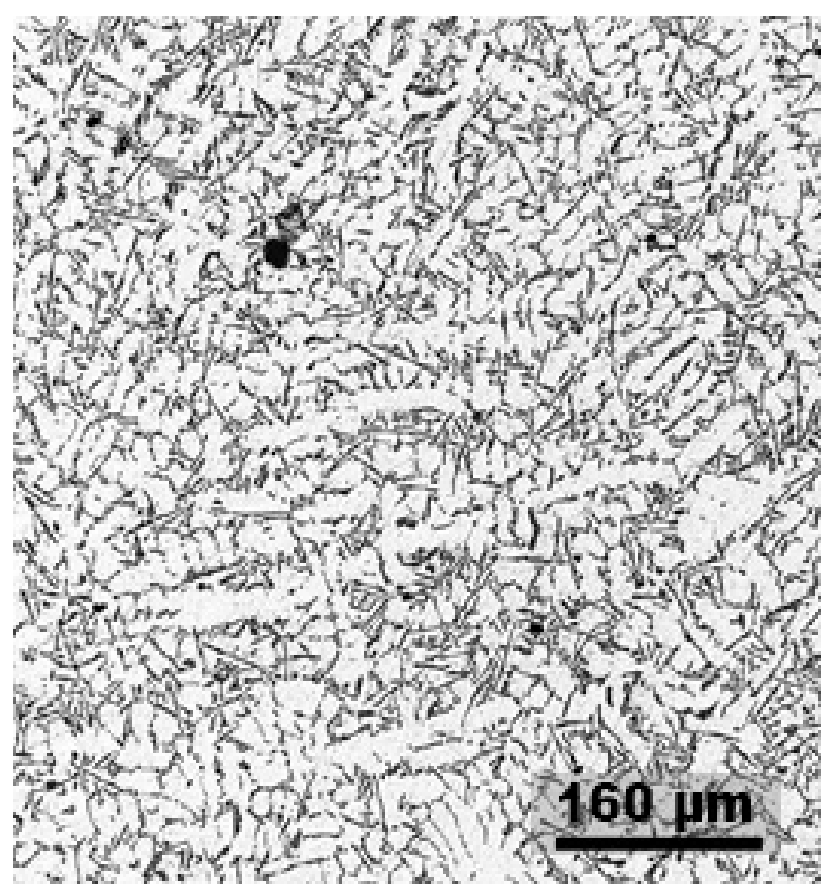

Fig.3 Sample A2, microstructure with porosity, mag. $100 x$

Tab. 3 Measurement of porosity of sample $A 2$ cast from AlSi10Mg alloy

\begin{tabular}{|c|c|c|c|c|c|c|c|c|c|c|c|}
\hline Measurement, $\mathrm{N}_{\circ}$ & 1 & 2 & 3 & 4 & 5 & 6 & 7 & 8 & 9 & 10 & $\begin{array}{c}\text { Arithmetic mean } \\
{[\% \text { of image area }]}\end{array}$ \\
\hline $\begin{array}{c}\text { Porosity } \\
\text { [\% of image area }]\end{array}$ & 0.13 & 0.05 & 0.02 & 0.03 & 0.05 & 0.09 & 0.08 & 0.13 & 0.03 & 0.06 & 0.057 \\
\hline
\end{tabular}

\section{Sample A3}

Figure 4 shows the microstructure of image analysis sample A3 with a porosity of $0.4 \%$. The measured porosity values of sample A3 are given in Tab. 4 . The average porosity value is $0.15 \%$ of the image area. The microstructure of sample A3 shows irregularly oriented dendritic cells. The primary axis of the dendrites is strongly oriented in one direction because of the intensive heat dissipation from the casting, which indicates the direction of the temperature gradient. The size of dendritic cells and intermetallic phases is significantly smaller compared to sample A1.

Tab. 4 Measurement of porosity of sample A3 cast from AlSi10Mg alloy

\begin{tabular}{|c|c|c|c|c|c|c|c|c|c|c|c|}
\hline Measurement, $\mathrm{N}_{\mathrm{o}}$ & 1 & 2 & 3 & 4 & 5 & 6 & 7 & 8 & 9 & 10 & $\begin{array}{c}\text { Arithmetic mean [\% } \\
\text { of image area }]\end{array}$ \\
\hline $\begin{array}{c}\text { Porosity } \\
\text { [\% of image area }]\end{array}$ & 0.1 & 0.1 & 0.1 & 0.3 & 0.1 & 0.15 & 0.31 & 0.2 & 0.42 & 0.28 & 0.15 \\
\hline
\end{tabular}



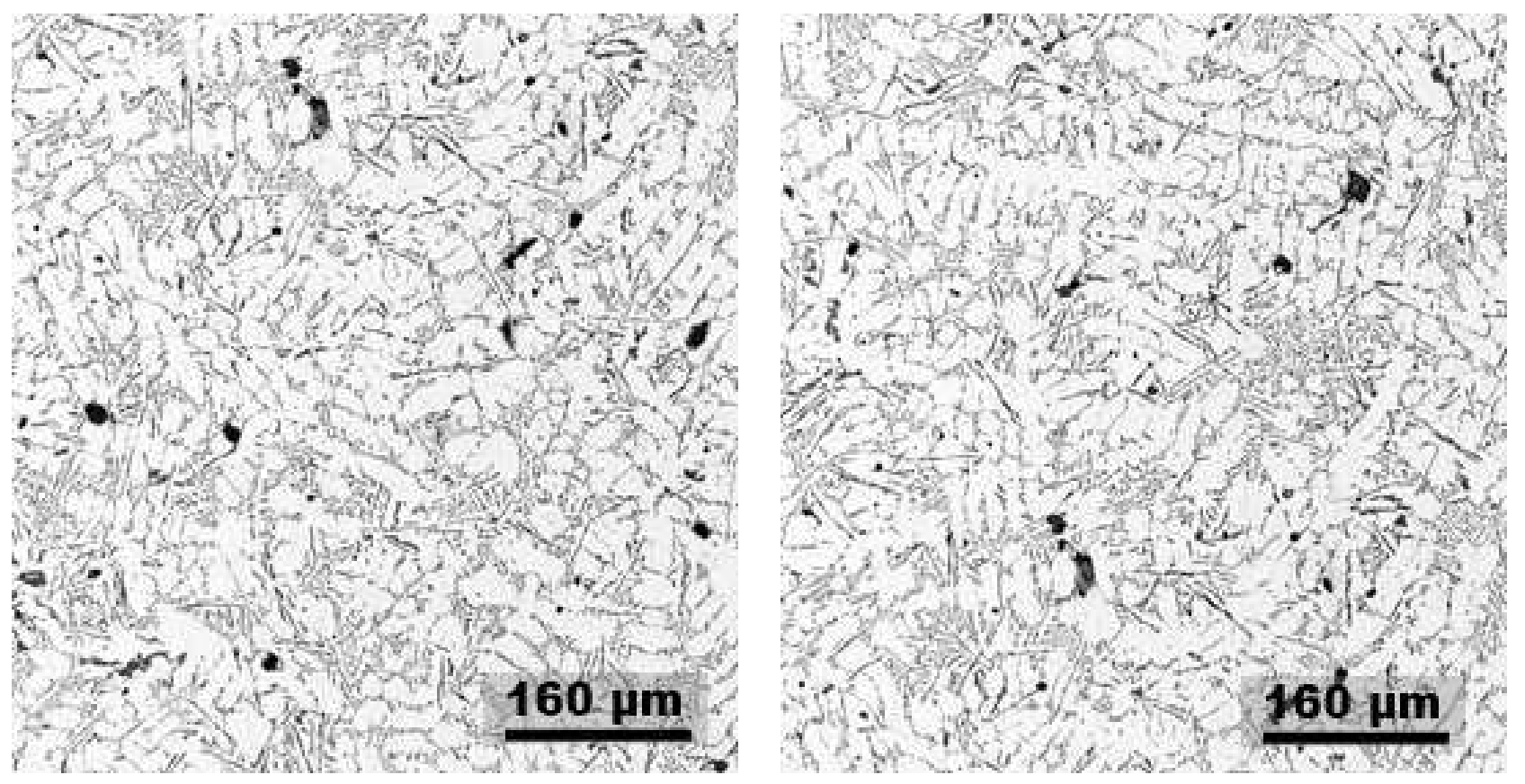

Fig. 4 Sample A3, microstructure with porosity, mag. $100 x$

\section{Sample A4}

Sample A4 was prepared from a portion of the casting in which the least macro-porosity was visually observed. The porosity values of the A4 sample are shown in Tab. 5. The average porosity value is $0.28 \%$

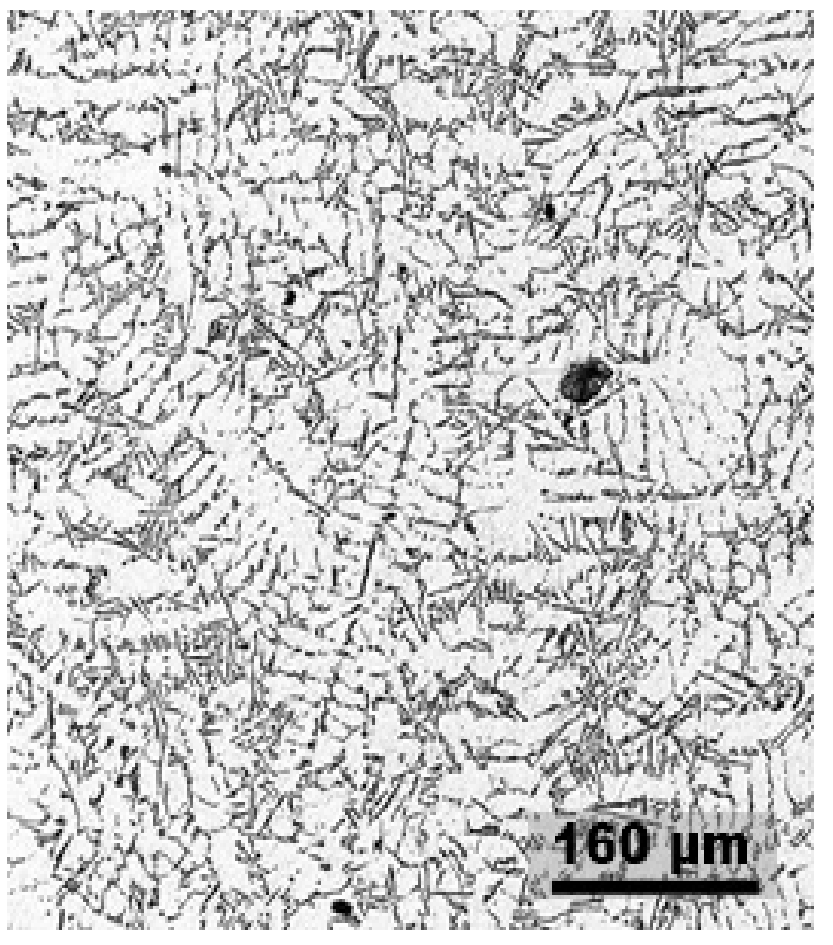

of the image area. As with all previous samples, the microstructure of sample A4 shows irregularly oriented dendritic cells. The microstructure of the sample is shown in Figure 5.

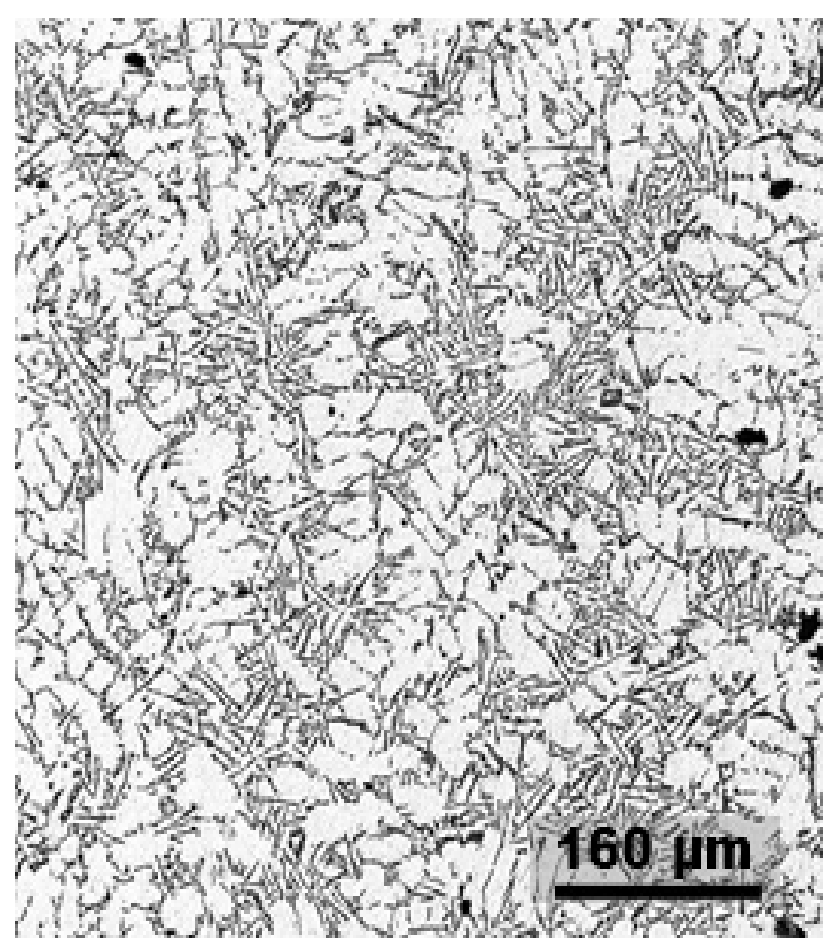

Fig. 5 Sample A4, microstructure with porosity, mag. $100 x$

Tab. 5 Measurement of porosity of sample A4 cast from AlSi10Mg alloy

\begin{tabular}{|c|c|c|c|c|c|c|c|c|c|c|c|}
\hline Measurement, $\mathrm{N}_{\mathrm{o}}$ & 1 & 2 & 3 & 4 & 5 & 6 & 7 & 8 & 9 & 10 & $\begin{array}{c}\text { Arithmetic mean [\% } \\
\text { of image area }]\end{array}$ \\
\hline $\begin{array}{c}\text { Porosity } \\
\text { [\% of image area }]\end{array}$ & 0.15 & 0.19 & 0.1 & 0.3 & 0.1 & 0.15 & 0.31 & 0.2 & 0.42 & 0.28 & 0.28 \\
\hline
\end{tabular}


From all measurements made, the addition of 0.05 wt. \% PROBAT FLUSS MIKRO 100 (A2) to the melt has the best impact and porosity dispersion effect in the resulting alloy structure. In the sample A1 without addition of the PROBAT FLUSS MIKRO 100, a large number of inclusions and pores are visible, as in samples A3 and A4. From a microstructural point of view, the optimum amount of PROBAT FLUSS MIKRO 100 is 0.05 wt. $\%$.

\subsection{Static tensile test according to ČSN EN ISO 6972 - 1}

In the second part of the experiment, specimens prepared from the experimental alloy AlSi10Mg were cast into a metal mold by the gravity casting method, which were then subjected to a statistical tensile test according to ČSN EN ISO 6972-1 (420310): 2017.
Test samples were prepared in 4 variants: test samples A1 are free of PROBAT FLUSS MIKRO 100, test samples A2 contain 0.05 wt. \% PROBAT FLUSS MIKRO 100, test samples A3 contain 0.1 wt. \% PROBAT FLUSS MIKRO 100 and test samples A4 contain 0.2 wt. $\%$ PROBAT FLUSS MIKRO 100. The test specimens were subjected to a static tensile test on the universal inspector 100 Hegewald \& Peschke.

The results of the static tensile test including the average values of strength and ductility are shown in the graph (Fig. 6). The samples were prepared from the same part of the castings studied (samples A1 A4). As can be seen from the graph, the addition of 0.05 wt. \% PROBAT FLUSS MIKRO 100 had the best impact on the strength properties of the alloy, resp. the highest values of strength - $160 \mathrm{MPa}$, and ductility $-4.2 \%$ were proved.

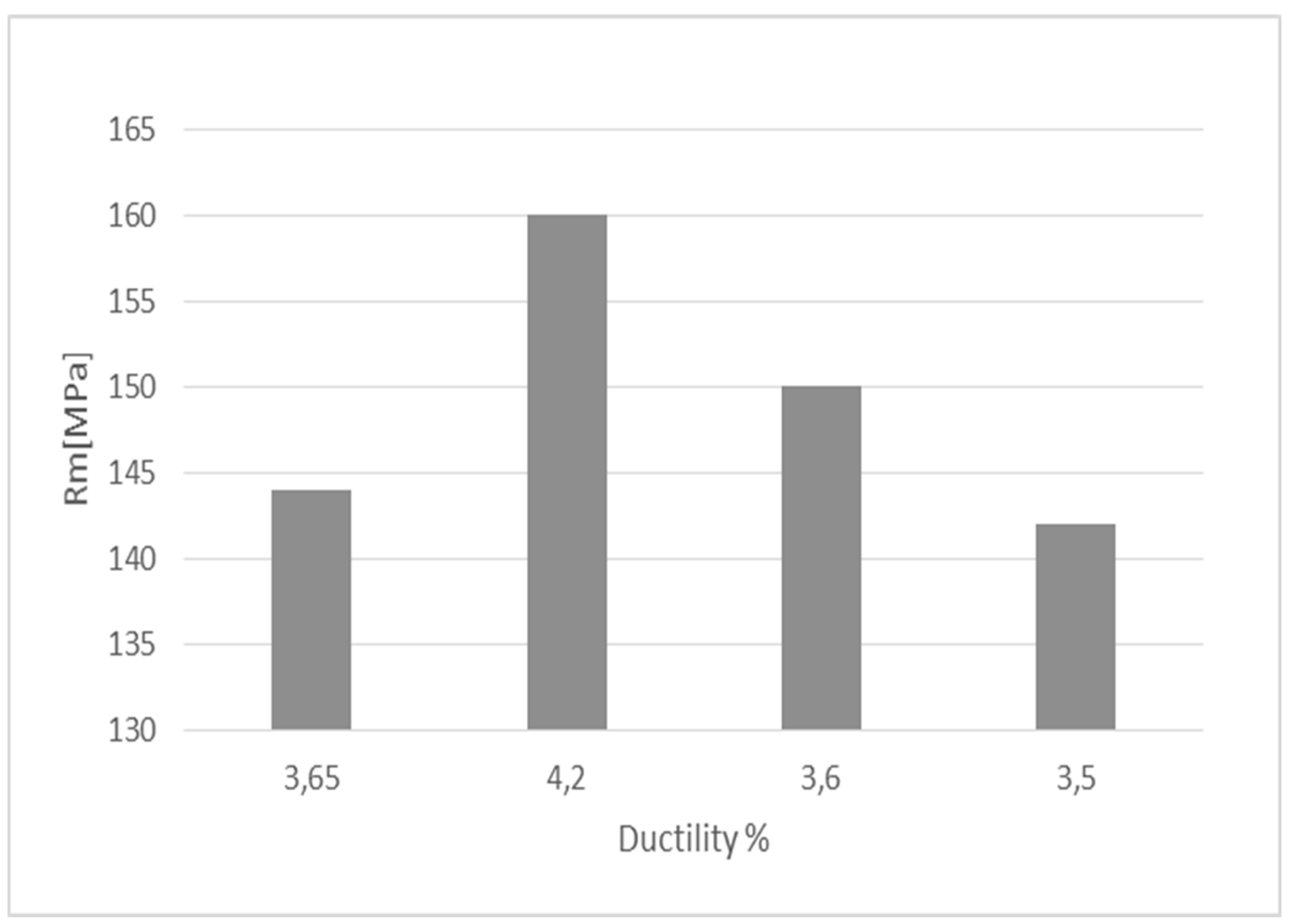

Fig. 6 Dependence of tensile strength on ductility, AlSi10Mg alloys

Figure 7 shows the dependence of tensile strength on porosity. As can be seen, the addition of PROBAT FLUSS MIKRO 100 at a concentration of 0.05 wt. \% has the best effect on the strength characteristics.
There is a relationship between tensile strength and porosity. When the porosity increases from $0.057 \%$ to $1.2 \%$, a tensile strength decrease of approximately $(15-20) \%$ can be observed. 


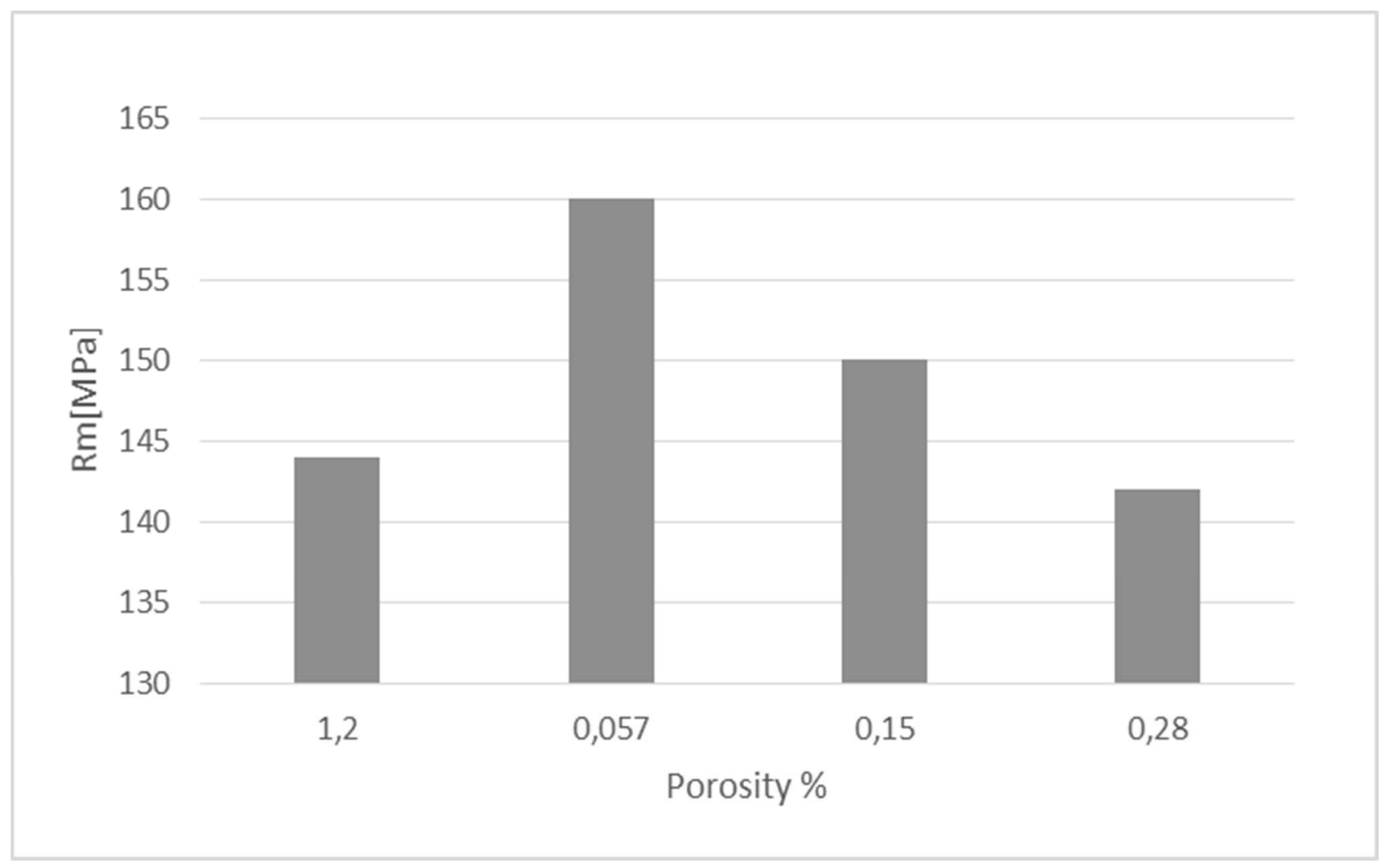

Fig. 7 Dependence of tensile strength on porosity of AlSi10Mg alloy

\section{Discussion and conclusion}

AlSi10Mg alloy, its structure and mechanical properties, in particular tensile strength and ductility, were characterized in connection with the use of the preparation PROBAT FLUSS MIKRO 100. Furthermore, several experiments evaluating the structure of the material were performed and described, especially in terms of microstructure by light microscopy.

The prepared samples from AlSi10Mg alloy were measured for porosity by microstructure image analysis as a percentage of porosity from the total image area. The range of porosity values is from $0.057 \%$ to $1.2 \%$. At a high degree of degassing, the alloy tends to form pores which can be expected to have a very adverse effect on the mechanical properties and pressure-tightness of the castings. At a higher hydrogen content, these cavities are transformed into a more compact type of relatively large gas pores from a microstructure perspective. Application of PROBAT FLUSS MIKRO 100 results in dispersal of the porosity and formation of very fine micro-pores,

After the static tensile test, the dependence between the porosity in the material structure and its mechanical properties was verified. Increasing the porosity in AlSi10Mg alloy from $0.057 \%$ to $1.2 \%$ reduced the tensile strength by $15 \%$. A porosity of $1.406 \%$ of the microstructure image area caused a tensile strength decrease of up to $20 \%$.
Based on the measured measurements and experimental results, it can be concluded that dispersion and refining of the pores allows to increase the strength properties of the AlSi10Mg alloy and it is known from the foundry practice that the presence of micro-pores does not cause loss of pressure tightness of the castings. Therefore, in order to eliminate the negative effect of porosity on the properties of AlSi10Mg alloy castings, the preparation of PROBAT FLUSS MIKRO 100 at a concentration of $0.05 \%$ can be recommended.

\section{Acknowledgements}

The article was created as a part of the project support with the support of grant UJEP-SGS2020-48-002-2 in Ústí nad Labem.

The article was created as a part of the project support with the support of grant UJEP-SGS2019-48-001-2 in Ústí nad Labem.

The article was created as a part of the project support with the support of grant UJEP-SGS2019-48-003-2 in Ústí nad Labem.

\section{References}

[1] MICHNA, S. et al. (2007). Aluminium Materials and Technologies from $A$ to $Z$, Adin, ISBN 978- 8089244-18-8. 
[2] KUSMIERCZAK, S., SLAVIK, M. (2018). Analysis of Al-Si layer on steel sheet during thermo mechanical processing using microscopic methods. In: Manufacturing Technology, Vol. 18, No. 5, pp. $769-774$

[3] LAGO, J., et al. (2016). Qualitative Evaluations of the AlSi7Mg0.3 Microstructure by the X-Ray Diffractometry. Manufacturing Technology, Vol. 16, No. 6, pp. $1284-1291$.

[4] HREN, I., SVOBODOVA, J., MICHNOVA, L., MICHNA, Š., BENEŠ, L. (2018). Research on the effect of beryllium on the modification and change of mechanical properties of Al-Si alloys. Advanced manufacturing and repair technologies in vehicle industry monograph, 2018, pp. 123 136.

[5] TIllová, E., CHALUPOVÁ, M., HURTALOVÁ, L., BONEK, M., DOBRZANSKI, L.A, (2011). Structural analysis of heat treated automotive cast alloy. In: Journal of Acbievements in Materials and Manufacturing Engineering/JAMME, Vol. 47, No. 1, pp. 1925.

[6] TILlOVA, E., CHALUPOVA, M., HURTALOVA, L., DURINIKOVA, E. (2011). Quality Control of Microstructure in Recycled Al-Si Cast Alloys. Manufacturing Technology, Vol. 11, No. 11, pp. 70-76.

[7] NÁPRSTKOVÁ, N., CAIS, J., SVOBODOVÁ, J. (2013). The Effect of Modification by Strontium of the AlSi7Mg0.3 Alloy on the Surface Roughness. Manufacturing Technology, Vol. 13, No. 3, pp. 380-384.

[8] MICHNA, Š., NÁPRSTKOVÁ, N., LUKÁČ, I. (2011). Mechanical Properties Optimization of AlSi12CuMgNi Alloy by Heat Treatment. Metallofizika i Noveishie Teknologii, Vol. 11.

[9] DOBRZANSKI, L., BOREK, W., MAZURKIEWICZ, J. (2015). Influence of Thermo-Mechanical Treatments on Structure and Mechanical Properties of High-Mn Steel. Advanced Materials research; Zurich1127, pp. 113119.

[10] HREN, I., MICHNA, Š., CAIS, J., LYSOŇ́KOVÁ, I., HODINÁŘ, L. (2018). Výzkum vlivu beryllia na modifikaci a změnu mechanických vlastností u slitiny $\mathrm{ASi} 7 \mathrm{Mg} 0.3$. Strojirrenská technologie, červen 2018, roč. XXIII, č. 1, ISSN $1211-4162$.

[11] KUSMIERCZAK, S., NAPRSTKOVA, N. (2018). Analysis of Al-Si layer on steel sheet during thermo mechanical processing using microscopic methods. Manufacturing Technology, Vol.18, No 5, pp. 769-774.

[12] MICHNA, Š., LUKÁČ, I. (2012). Praktická fraktografie. OPTYS, spol. s r.o., Univerzita J. E. Purkyně v Ústí nad Labem, s. 237.

[13] ČSN EN 1796 - Hliník a slitiny bliníku - Odlitky - Chemické složení a mechanické vlastnosti

[14] L. BACKERUD, L., CHAI, G., TAMMINEN, J. (1990). Solidification Characteristics of Aluminum Alloys. Foundry Alloys, Vol. 2, pp. 25-38. 